\title{
The multifarious interlinked causes of conflict in Somalia and the way forward
}

\section{Catherine Wanjiku Nyambura}

\begin{abstract}
This article has identified the factors influencing achievement of sustainable peace in former Italian Somaliland (currently known as Somalia) since 1960. The study was conducted with the objective of establishing the internal and external factors influencing sustainable peace in Somalia. The factors studied are clanism, religion, politics, economy, piracy, and peace agreements, United Nations, United States, Italy, African Union, Al-Qaeda and the Arab League. It also explored possible solutions that could be implemented to achieve sustainable peace in Somalia.

The study found that the internal factors of clanism and religion can be positively influenced to bring back peace in Somalia while piracy, politics and the economy were seen to be hindering efforts for sustainable peace. On the external factors the study confirmed that the United Nations has not given enough assistance to Somalis to enable them end the continuous conflict and bring sustainable peace. The study also explored solutions that could lead to sustainable peace; some of the suggested solutions include disarming the outlawed groups and the civilians, unified international support on peace initiatives and strengthening local institutions that could be used as vehicles to peace. In the efforts to achieve sustainable peace the report of this study has recommended that Somalia army should be strengthened to be able to protect its people instead of having foreign armies such as Ethiopian troops and AMISOM. The locals should own the peace processes and the agreements should be made in Somalia instead of holding them in other countries.
\end{abstract}

\section{Introduction}

Since ousting of President Siad Barre in 1991 it has been difficult to achieve peace in Somalia for several reasons, namely the emergence of warlords and other interest groups who are thirsty for power; the destruction of major institutions like courts of justice, and social disconnection. Indeed, after the break-out of the many Somalis went to seek refuge abroad or in the neighbouring countries leaving vulnerable people 
behind. The latter have not been able to solve the problem, due to inability to agree on the center for power and desire for all to be leaders, failure by the citizens to trust their own government probably because of the atrocities done by the former regime, political rivalry and divisive politics, formation of weak governments that are threatened by outlawed militia groups, International community and neighbouring governments meddling with the internal affairs of the Somalis, and prolonged war in Somalia occasioning fatigue. The multifarious interlinked causes of conflict were investigated in detail in order to show how they affect sustainable peace in Somalia and a way forward was also suggested.

\section{Objectives of the study}

The following are the objectives that guided the study

1. To establish the role played by internal factors in efforts to achieve sustainable peace in Somalia

2. To examine the role-played by external factors in the achievement of sustainable peace in Somalia

3. To explore possible solutions that can lead to achievement of sustainable peace in Somalia

\section{Research Questions}

The research will be guided by the following questions:

1. What is the role of internal factors in the effort to achieve sustainable peace in Somalia?

2. What is the role of external factors in the effort to achieve sustainable peace in Somalia?

3. Which are the possible solutions that can lead to achievement of sustainable peace in Somalia?

\section{Research Methodology}

To achieve the objectives of this study direct observation, secondary and primary data collection methods were used. The instruments used to collect primary data was open ended questionnaires, each item in the questionnaire was developed to address a specific research question or objective. The open-ended questionnaires were used to 
encourage the respondents to give in-depth information without feeling held back in revealing any information. For the secondary data existing records and information was used while for observation an observation schedule was used. These different methods were used to triangulate and augment the data collected. The researcher used descriptive survey method where the practices that prevailed were described which among others included: peoples believes, views, attitudes or perceptions that are held. This involved questioning people and recording their responses for analysis. This method enabled the researcher to gather extensive information from the respondents. This study involved qualitative data collection approach and therefore content analysis was used.

\section{Background information on Somalia}

Historically, the current Somalia conflict can be traced back to the $19^{\text {th }}$ century, when Great Britain, Italy, France and Ethiopia divided the Somali-inhabited territories of the Horn into five distinct political jurisdictions (Abdulle \& Ali, 2004). The territories were The British Somaliland Protectorate (current Somaliland), The Italian Somaliland (Somali Republic), French Somaliland (the present day Republic of Djibouti upon achieving independence in 1977), and The Northern Frontier District (NFD) of Kenya and The Ogaden region of Ethiopia.

Various attempts were made to reunite the Somalis under a single flag. Despite these efforts only 2 Somali territories actually managed to merge. British Somaliland became independent in June 261960 and Italian Somaliland that achieved independence 4 days later on July $1^{\text {st }}$ 1960. However in 1991, British Somaliland broke from wider Somalia after the fall of Siad Barre's regime. It has undertaken democracy without official recognition or support from the international community (Large, 2006). The failure to incorporate the remaining Somalia-inhabited territories into the new Somali Republic has and continues to have enduring consequences for the peace and security in the Horn of Africa region.

Somalia has an area of $637,657 \mathrm{~km}^{2}$ and is located on the East Coast of Africa and North of the Equator with Ethiopia, Djibouti and Kenya as its neighbours. This region is often referred to as the Horn of Africa. According to the 2004 African 
Development Report Somalia had a population of 9,890,000 in 2003 where $99.9 \%$ of the population was Muslims. The languages spoken in Somalia include Italian, Arabic, English and Somali. Somali is the official language (Bureau of African Affairs US, 2009). Somalia gained independence in 1960 and unlike most African States it had a strong sense of national identity. Somalis possess a common language, culture and they also share a profound attachment to Islam (Meredith, 2006). The immediate cause of conflict in Somalia was related to crises in governance. The democratic principles were being enacted at the top level while nepotism, corruption and clan competition were rapidly eroding the underpinnings of Somalia's nascent democratic system. The Political misrule, combined with pervasive corruption, hampered the maturity of administrative institutions and undermined development of the country's embryonic social services network, thereby engendering general disillusionment with the entire system (Abdulle \& Ali, 2004). The exploitation of clan identity by political opportunists swiftly gave rise to an unwieldy number of clan based political parties (Mukhtar, 2003).

The root cause of the problem can be traced to the rapid marriage of the two Somali territories (North formerly British Somaliland and South formerly under Italian rule) to form the first 'united' state in 1960 (Adam, 1994). After the union, Southerners held all major posts in the government. The government programmes failed to tackle the serious problems of underdevelopment and socio-economic stratification in the North inherited from the colonial administration (Adedeji, 1999). The Rehanwein of the Riverine region, who enjoyed an equal number of seats with the two other major clans the Hawiye and Darod prior to unification, were comparatively marginalized, and faced discrimination both in the education and government sectors. This means the war in Somalia began long before the state collapse in 1991. The table 1.1 shows how the state of Somalia continued to deteriorate and eventually collapse in 1991. 
Table 1.1 The following are the major actions that took place in Somalia from 1960 to 1991 when the president Siad Barre government was overthrown. The table explains the events that took place and could have contributed to collapse of the state.

Table 1.1 The genesis of Conflict in Somalia from 1960 to 1991

\begin{tabular}{|c|c|}
\hline Year & Action \\
\hline 1960 & $\begin{array}{l}\text { Independence of Somalia and unification of the two regions as the Somalia republic ( British Somaliland \& Italian } \\
\text { Somaliland }\end{array}$ \\
\hline 1961 & $\begin{array}{l}\text { Referendum for the first Somalia constitution } \\
\text { First Presidential election, Adam Abdulle Osman defeated opponent by one vote. Osman to rule for } 6 \text { years. }\end{array}$ \\
\hline 1964 & First general election after independence and unity \\
\hline 1967 & 2nd presidential election, Abdirashid Shermake won against Osman \\
\hline 1969 & $\begin{array}{l}\text { 2nd general election and the polarization of clan parties, } 21 \text { st October Shermake assassinated by one of his body } \\
\text { guards. On } 21 \text { October A military coup led by Siad Barre establishes the Supreme Revolutionary Council (SRC) } \\
\text { to govern the republic. }\end{array}$ \\
\hline 1972 & Somali- Soviet agreement \\
\hline 1974 & Somalia joins the League of Arab States \\
\hline 1976 & Formation of Somali Revolutionary Socialist Party (SRSP) \\
\hline 1977 & Somali National Army defeated in hands of Ethiopians in 1977 during the Ogaden war \\
\hline 1979 & Referendum for the 2 nd Somali constitution \\
\hline 1980 & Somalia agrees to give United States access to military port and airfield at Berbera \\
\hline 1981 & Formation of Somalia National Movement an Issaq clan based opposition group. \\
\hline 1988 & $\begin{array}{l}\text { Somali signs a peace treaty with Ethiopia, renouncing its claim to the Ogaden. After the peace treaty the army and } \\
\text { air force bombard Hargeisa and Burao, centers of opposition to Barre driving an estimated 300,000 Issaqs into } \\
\text { Ethiopia as refugees }\end{array}$ \\
\hline 1989 & $\begin{array}{l}\text { United Somali Congress, a Hawiye based opposition is formed and Somali Democratic Movement and Raween } \\
\text { opposition group }\end{array}$ \\
\hline 1990 & $\begin{array}{l}114 \text { religious leaders, business men and political leaders known as manifestos call for Barre's resignation and a } \\
\text { national reconciliation conference to create an interim government. }\end{array}$ \\
\hline 1991 & $\begin{array}{l}\text { Downfall of Mohamed Siad Barre's Regime } \\
\text { The Issaq dominated SNM announces its secession and declares its independence as the Somaliland Republic }\end{array}$ \\
\hline
\end{tabular}

Sources: (Adam \& Ford, 1997; Mukhtar, 2003) 
On $26^{\text {th }}$ January 1991, Somalis everywhere received with jubilation the news of President Siad Barre's flight from Mogadishu because they thought that that was the end of dictatorial leadership. But a new chapter in Somalia's tragic history was beginning to unfold as the unbridled political opportunism of the 1960 re-emerged with a vengeance. Even as the United Somali Congress (USC) which was dominated by Hawiye clan succeeded in capturing the City, it was unable to contain the ensuing chaos and anarchy (Adedeji, 1999). This confirmed they were not ready for the change they were looking for and today the Somalis are still trying to contain the situation. In African societies, the political ruling elite has shown no restrain in manipulating the people through prejudice and stereotypes about other ethnic groups in order to win their support for achieving their own self-centered objectives (Adedeji, 1999). The current crisis in Somalia is the product of multifarious interlinked causes, as diverse as the lingering effects of colonization, the dislocation of forced urbanization and the stresses of globalization. For close to two decades Somalis continue to suffer the brunt of a relentless war.

Since 1991 Somalis have never been able to contain the situation and conflict continues to flare up claiming many innocent civilians. The protracted conflict in Somalia has resulted to several attempts of peace agreements recording the largest number of unsuccessful peace agreements anywhere in Africa between 1991 to 2009. There have been twelve such attempts including: Djibouti National Reconciliation in 1991, Addis Ababa Agreement in Ethiopia in 1993, Somali National Reconciliation Conference held in Kenya in 2004, Khartoum Reconciliation in Sudan in 2006, National Reconciliation Congress in Somalia in 2007 and Djibouti Agreement in 2008 that resulted to President Sheikh Sharif Sheikh Ahmed being elected as the Transitional Federal Government president in January 2009 after the resignation of President Abdullahi Yusuf in December 2008.

\section{Statement of the Problem}

Since the collapse of the government in 1991, Somalia has been in search of sustainable peace as demonstrated through the various peace agreements negotiated. However, the search for peace has, for all practical purposes, been elusive. The 
researcher investigated the internal and external factors influencing the achievement of sustainable peace and further explore possible solutions that could lead to peace for Somalis

\section{Limitations of the study}

The limitations of the study arose from methodology used. The methodology employed as indicated in chapter three is purposive sampling and was conducted in Nairobi. The persons surveyed may not have been the best representation of diverse players involved in Somalia conflict. Also due to the constant changing environments, the faction perceived strong today may be disempowered tomorrow and therefore the conclusions made can be challenged or affirmed by another study in future.

\section{Somalia Conflict Situation from 1960 to 2009}

After independence there was a more immediate cause of the Somalia conflict, related to various crises in governance in the postcolonial period 1960 to 1969 . During the 1964 and 1967 elections, the government engaged in widespread fraud aimed at guaranteeing electoral victory for candidates fielded by the ruling Somali Youth League (SYL). Public outrage after the 1967 elections translated into angry demonstrations, clashes between government security forces and members of the public and incidents of interclan violence. Following the elections, sporadic incidents of violence continued and public confidence in the government fell to a new low (Abdulle \& Ali, 2004).

The government's scorched-earth policy and its growing intolerance of suspected opponents created a backlash, providing the insurgents with an ever-widening base of support. In 1982 the conflict spread to the Northwest where the Somali National Movement (SNM), an Issaq dominated political organization took up arms to overthrow Siad Barre's regime (Mukhtar, 2003). The SNM waged continuous guerilla war until the government collapsed in 1991. Somali began to disintegrate, fragmenting into a patchwork of rival fiefdoms controlled by heavily armed clan chiefs. The Darod (Ogaden clan) formed Somali Patriotic Movement (SPM); the Hawiye formed United Somali Congress (USC) in the Central region; and the army splintered into rival factions causing banditry, extortions and lawlessness to become commonplace. According to one of Siad's close friends, Siad repeatedly vowed thus: 
"When I leave Somalia, I will leave behind buildings but no people" (as cited in Dualeh, 2002, p.37)

Uncontrolled armed militia ransacked the capital.The subsequent interclan conflict between the Darod and Hawiye led to the suffering and death of defenseless civilians of both clans and the other unarmed clans. Almost all non-Hawiye clans, but especially the Darod and other minorities fled Mogadishu from fear of persecution or otherwise. One wing of the United Somali Congress (USC) leadership, in cooperation with the Somali National Reconciliation Committee established by president Barre, abandoned its commitment to armed allies elsewhere in the country and unilaterally appointed a new president. The split within the USC triggered the outbreak of civil war across much of South and Central Somalia (Abdulle \& Ali 2004). From this time onward Somalia continued to suffer many human atrocities, power struggles among various factions and a raging war that continues to this day. The table 2.1 shows the peace agreements developments from 1991 to 2009 and other major steps taken in the efforts to end conflict after ousting of President Siad Barre.

Table 2.1 Peace agreement Developments in Somalia from 1991 to 2009

\begin{tabular}{|l|l|}
\hline Year & Action \\
\hline 1991 & National reconciliation conference hosted by Djibouti in July \\
\hline 1992 & No major action \\
\hline 1993 & Addis Ababa agreement hosted in Ethiopia \\
\hline 1994 & No major action \\
\hline 1995 & No major action \\
\hline 1996 & The Sodere agreement \\
\hline 1997 & The Cairo agreement hosted in Egypt \\
\hline 1998 & No major action \\
\hline 1999 & No major action \\
\hline 2000 & The Arta agreement hosted in Djibouti \\
\hline 2001 & No major action \\
\hline 2002 & Kenyan effort to bring together the Transitional National Government and opposition failed \\
\hline
\end{tabular}




\begin{tabular}{|c|c|}
\hline & Signing of Declaration on cessation of hostilities held in eldoret, Kenya \\
\hline 2003 & Amendment of Transitional Federal Charter held in Kenya \\
\hline 2004 & Inauguration of Federal Transitional Parliament hosted by Kenya \\
\hline 2005 & June 2005 Abdullahi Yusuf Ahmed Elected as president of TFG \\
\hline 2006 & $\begin{array}{l}\text { Alliance of Islamic courts took control of Mogadishu in June } 2006 \\
\text { Signing of Khartoum } 1 \text { agreement to recognize TFG and ICU, this was never implemented and fighting broke out in December } 2006 \\
\text { in which the Somalis, backed by Ethiopian troops defeated the ICU. }\end{array}$ \\
\hline 2007 & $\begin{array}{l}\text { National Reconciliation Congress held in Mogadishu with participation of 2,600 delegates representing clans, women and Diaspora. } \\
\text { ARS (Re-liberation of Somalia) was established by former parliamentarians and Islamic courts Union in Asmara, September }\end{array}$ \\
\hline 2008 & $\begin{array}{l}\text { TFG and ARS signed Djibouti agreement in August } 2008 \text { witnessed by international community including AU, IGAD, US, UK, EU, } \\
\text { France, Saudi Arabia and Djibouti. } \\
\text { December 29th } 2008 \text { President Abdullahi Yusuf resigned }\end{array}$ \\
\hline 2009 & $\begin{array}{l}\text { Withdrawal of Ethiopian troops from Somalia } \\
\text { On } 31 \text { st January } 2009 \text { chairman of ARS, Sheikh Sharif Sheikh Ahmed elected as Somalia's new president, he ran against former } \\
\text { Somalia president Siad Barre, Maslah Mohamed Siyad, Omar Abdirashid Ali Sharmake appointed as the Prime Minister by } \\
\text { president Sheikh Sharif on February 13th } 2009 \text {. }\end{array}$ \\
\hline
\end{tabular}

Source: United Nations Political Office for Somalia December 2009 (Modified by the researcher)

\section{Research Findings}

The research was carried out between November 2009 and August 2010. The findings revealed the various factors that could be contributing to continuous conflict in Somalia. The factors were divided into internal and external. The internal factors investigated in this study included: Clanism, politics, economics, piracy, peace agreements and religion. While external factors included: United Nations, United States, Arab League, Al-Qaeda, African Union and Italy.

\section{Internal Factors influencing achievement of sustainable peace}

Let us look at each internal factor and its roles according to the research findings. The concept of clans in Somalia has been popular in terms of helping the community. Clan elders have played a role in assisting and solving interclan disputes through mediation 
on behalf of a member of a certain clan where there is an inter clan dispute. They have also actively been involved in mobilizing their members to participate in peace process locally. On the other hand, Clanism has been largely blamed on fuelling the war in Somalia due to supremacy wars and disrespect among other clans arising from the majority and minority clans mentality.

On the political side, Transitional Federal Government (TFG) is the officially recognized structure but it is struggling to maintain local support and the other group that was perceived to be strong was The Al-Shabab. This group during the time when this research was conducted commanded a larger area in Somalia than that of the TFG, however they have split and this is likely to contribute to them being weaker force. Other major group includes Ahlsunna Waljama which is also in the forefront in the scrumble for Somali's land. All this groups are in such of the top job in the country and ultimately having a peaceful Somalia.The reasearch revealed that these groups are not working alone, but also have those who believe in them and therefore have both financial and human resource support. TFG being the accepted political structure enjoys support from African Union, United Nations and United States all with faith that their assistance will one day translate to peace and government trusted by the people. However the TFG has not had any visible impact on efforts to bring sustainable peace in Somalia.The respondents pointed out another hindrance to achievement of peace in Somalia to be the the international communitybecause they are perceived to have vested interests in the Somalia government. Although it was evident from the respondents that both internal and external factors are seen to have vested interests. The interests were not outlined and therefore the need to do more exploration to establish these interests.

On the economy side of Somalia in relation to the ongoing conflict it was observed that Land disputes, business-related income sources like sea and airport and pastoral lands are the major economic factors leading to chaos. Being an arid and semi-arid region, Somalia draws its main economic activities from livestock keeping, farming, business and international trade. From the study, piracy has become very popular business oriented and has got significant economic and commanding political power.Some of these funds could be spilling to the Kenya economy especially in business and real estates. Piracy, has contributed to insecurity along the Somalia 
waters. It is believed that piracy is playing an important role in safeguarding the Somalia waters from Western fishermen. But, their illegal activities along the shores especially of hijacking ships and kidnapping highly outweigh their perceived good intention by the civilians. Religion has always been key to good morals and upbringing within the Islamic community. The study established that selfunderstanding and interpretation of Islamic scriptures was the major factor of clashes between Islamists and other groups. Different interest group use religion to justify their ideology, which has a bearing on peace. However, religion is good and is one of the factors that can be influenced in achieving stable peace in Somalia. If respected, it has the power of uniting and solving the differences amongst people giving them a common platform for sustainable peace

\section{External factors influencing achievement of sustained peace in Somalia}

Despite the fact that the UN has been in Somalia for many years, according to the research, the United Nations is seen as a negative force that represents the West. Islamists use this ideology to influence people against UN support; the UN has also been accused of financing and supporting TFG which is perceived to be weak by the civilians. This is because thay command a small area and do not give enough support to its own people who suffer and continue to bare the brant of the protracted civil war. On the other hand UN has mediated in several peace agreements for SomaliaThe United States has also supported in peace processbesides all these efforts we still have a quest for peace in Somalia. Besides supporting peace initiatives the UN and United States has been providing humanitarian assistance, by providing food, water and medical assistance to affected families.

Even with the tremendous humanitarian assistance offered, the respondents perceives the US to be negatively involved on peace efforts as they have embarked on a series of attacks on the militia that are derailing the establishment of peace process in Somalia. According to omar (2004) "After September 11, 2001 attack on New York town towers and the pentagon the President of the U.S expressed his determination to extend what he called "war against terrorism" to include Somalia". The US has been accused of fighting Somalis in the name of fighting criminals such as pirates and terrorists like Al Qaeda. Indeed as pointed out by (Phillips, 2002) 
"Largely expelled from Afghanistan, Al-Qaeda may seek to regroup in another country where it could count on some degree of local support, Somalia is such a place. It is a failed state whose lawless anarchy would permit terrorists to operate relatively freely. The Al-Qaeda network has operated there in the past and has long standing ties to a small minority of Somali Islamists, with which it has worked since 1990s"

Another important player, but quiet, is Italy who also colonized Southern Somalia. The research revealed that Italy has constantly participated in dialogue with the concerned parties aiming at resolving the issues affecting Somalia. Further, the Italians have helped by organizing different workshops to try and bring the warring parties together. On the humanitarian spacethey have provided medical assistance to the victims of war. Italy is not very visible and its role on peace in Somalia is seen to be minimal.

Crossing to the African continent and efforts to guide peace, the African Mision to Somalia are based in Mogadishu with a mandate to back up the TFG military and ultimately the Somali people. Some locals feel that if better equipped personnel are deployed, AMISOM will be more effective in achieving its peace objectives. Besides Amisom, there are individual countries providing some support to Somalia, among them include: Ethiopia, Eritrea, Djibouti and Kenya to mention but a few. Despite the questionable relationship between Somalia and Ethiopia due to Ogaden war of 1977, Ethiopia has helped in initiating peace process as well as putting pressure on the warring communities to end conflict. On the other hand, Eritrea has been accused of supporting the Al-Shabab and militia groups who support Islamic laws. The Eritreans army has been accused of fighting alongside the militia. In addition, Eritrea has been blamed for allowing being the route passage of arms to Somalia. Kenya has greatly helped Somalia in trying to achieve peace and stability; it has played a key role in peace initiative to an extent of even setting up a secretariat to spearhead and guide the peace process and further hosted the Somali national reconciliation conference and was mediator in the peace process. 
The Arab League has helped in peace initiatives in Somalia by championing the interests of the Muslims at large. However, Arab league has not succeeded in efforts to achieving sustainable peace. Other players involved in Somalia situation include Pakistan, Afghanistan, Yemen, Ddibouti, the Diaspora, the Alqaeida and the European Union.

\section{Possible Solutions that can lead to achieving sustainable peace}

For peace to prevail, the research found out that Somalia should first involve all the conflicting parties, both internal and external, in their peace negotiations. To further improve security the outlawed groups and civilians should be disarmed and Somalis encouraged to join together for peace and speak in one voice to end conflictThe international community should as well be cautious on financing individual clans, militia and other interest groups involved directly in conflict. They should be engaged in dialogue with the warring parties without taking sides and support an outcome that would lead to sustainable peace. Due to the severe humanitarian assistance and low economic development they should also provide good infrastructure and initiate development to revive up the economy. Both the international community and Somalia should be fully dedicated to implementation of peace initiatives. Furthermore the international community should avail more resources to facilitate the peace process, and also educate the Somalia people by creating peace programs for children, the youth and the adults. The Transitional Federal Government or ant other government structure within Somalia which is recognized and respected by the people should have a strong army.to keep peace instead of having foreign troops to protect them. Efforts should be put to ensure that the governemnt is seen to represent the people of Somalia and not to meet interests of a few persons. Moreover, Somalia should elect a national leader who is strong and committed to the peace agenda. On the other hand, the international community should offer their support to ensure peace is maintained.The following are some of the ways that can be used to achieve sustainable peace in Somalia.

\section{a) Forming a functioning and strong Government in Somalia}


A functioning government in Somalia that is fully inclusive and respected by the Somalis should be formed. The Government's military should have the mechanisms to protect its people from the chronic insecurity and they should create confidence in their citizens. A well-structured government with police, military, law and order is an asset in ending the conflict. The government should be assisted with manpower and finances to create functioning institutions ready to steer development in various sectors and ultimately improving the economy and creating employment for its citizens. Elect a diplomatic, nationalistic and visionary leader. When civilians view a leader as diplomatic, nationalistic and visionary they appreciate him. The internal and external players should invest towards ensuring the leader elected has good qualities and will be respected and accepted by Somalis. The international community should provide means for power sharing after forming a new government and this will give a sense of full representation by all clans.

\section{b) Disarm the Militia and other outlawed groups to reduce their power}

In the current years different groups have emerged including the Al-Shabab community warlords, Hizbul Islam and Ahlusunna waljama. These groups are interested in power and ruling Somalia. They are fully armed and pose a threat to civilians; in addition they have recruited innocent children and youth into their groups. . The necessary efforts should be put to disarm these groups and also the armed civilians to minimize levels of killings. If these groups are disarmed the government can strengthen its army to protect the people without posing a high threat on themselves. The Somalis should be ready to do away with outlawed groups so that it is easier to implement justice and order. If negotiations fail then they should engage in war and disarm them by force and take over the country. Sanctions should be put in place to control weapons getting into Somalia.

\section{d) Unified International support}

It is clear from the respondents that the International Community's support is not consolidated; they must come together and support same initiatives in order to succeed. Common strategies will be necessary if the international community is to fight the outlawed groups in Somalia. The international community should be committed to supporting peace initiatives from locals at any time. They must be ready 
to avail fund and human power to support these initiatives and ensure that they fully involve Somalis in decision-making.

\section{e) Strengthen local institutions and initiatives on peace}

In Somalia there has been degeneration of traditional institutions, which were responsible for settling disputes such as courts and clan elders. These institutions became powerless and are no longer respected hence people break rules with impunity. These traditional institutions should be revived and strengthened. For peace to be achieved, Somalis should appreciate their own support and leadership and include the clan elders, religious leaders and other charismatic leaders in peace efforts. In addition, peace conference should be organized inside Somalia so that they can be owned locally. Furthermore, the peace process should be able to look at the underlying causes of conflict.

\section{Recommendations on the way forward}

In a country that has been in conflict for close two decades, the people are suffering and for the country to revive and come back to peace the following measures must be taken.

\section{Strengthen internal army}

The neighbours or international community is always helping out Somalia. The Somalis need to use own armies and not armies of other countries. As Machiavelli asserts "unless Somalia commands its own arms no principality is secure rather it is dependent on future since there is no valour and loyalty to defend it when adversity come" Further he says "nothing is so weak or unstable as a reputation for power which is not based on ones own forces" borrowed armies will have difficulties maintaining peace as when they withdraw the government will always be defeated by the militia groups who have own army. The Somalis must have a homegrown Somalia Army that will be respected and is inclusive of all including the armed clans and militia groups.

\section{Formation of new States}


Somalia could also attempt to form new states with independent leadership such as Puntland that was founded in 2000. Other states that Somalia could form to minimize conflict are Banadir state where Mogadishu can be the capital and Juba state where Baidoa can be the capital.

\section{Peace must be locally owned}

It must be ensured that priorities are determined locally, it is therefore crucial that spaces and processes exist where consensus building and dialogue can take place. If local people and groups participate in defining the problem they can be engaged to take ownership also of solutions. Peace agreements/negotiations should be done at home because holding them in other countries shows that those engaging in negotiations are actually scared of the militia and this strengthens them indirectly. The civilians cannot identify governments formed in other countries and will always perceive them as being foreign. The peace negotiations should also be done in phases instead of one off meetings this will give others a chance to be involved in the next one if they miss one.

\section{Clan Traditional Mythology}

Somalis must have the will to end the traditional mythology of viewing ones clan as self righteous, largest, bravest, wisest and most deserving to rule the other clans. They must result to win-win elections. There has been continuous dissatisfaction and betrayal especially during peace negotiations. The question, from whom were you born is still a big issue that could be hidden under the carpet. The functioning government should encourage Somalis nationalism and no government positions or resources should be granted according to ones clan.

\section{Reward by the International Community for peace milestones achieved}

The UN and other nations should find ways of supporting Puntland, Somaliland and Transitional Federal Government also give military assistance. With a prosperous Somaliland, Puntland and functioning TFG trouble makers would attract fewer followers. 


\section{Conclusion}

This study has carefully revealed the Internal and External factors influencing sustainable peace in Somalia and has further provided suggestions on how peace can be achieved within the country. The first objective of the study was the identification of the internal factors influencing sustainable peace in Somalia; the study found out that clans should be enhanced to support peace initiatives and not be triggered to cause conflict. The study has also revealed that religion is good for peace; religion shapes most societies and the religion of Islam is not an exception. Nonetheless, care must be taken to avoid the promotion of fundamentalists who are out to abuse religion. With respect to politics, the study established that TFG Al-Shababs, Ahlusunna waljama and Hizbul Islam groups are weak in governance. Majority of the respondents revealed that the factions are more on the negative side when it comes to promoting peace this is due to competition, lack of interest and loyalty.

The second objective of the study was the identification of the External factors influencing sustainable peace. It was confirmed that United Nations role on peace in Somalia is perceived negatively and another avenue or mediator needs to be sought to resolve the problem.

The third Objective of the study was the proposal of possible solutions that can lead to the achievement of sustainable peace in Somalia. It was revealed that Somalis are tired with war and it is the right time to advocate for peace. One of the key solutions is to allow peace initiatives and agreements be locally driven rather than being created outside and therefore stirring a feeling among the Somalis of imposition of External initiatives. 


\section{References}

Abdulahi \& Henderson. (2007). African Journal on conflict Resolution, vol 7 Retrieved November 19, 2008 from www.accord.org.za/index.php

Adam, H.M. (1994). Formation and recognition of new states. Somaliland in contrast to Eritrea, Review of African Political economy.

Adedeji, A .(1999). Comprehending and Mastering African Conflicts: Sustainable peace and good governance. Zed Books: London \& New York.

Dualeh, H. A .(2002). Search for a new Somali Identity. Nairobi: Government printing press.

Lapidus, I. M .(1997). A history of Islamic Societies. UK Cambridge University Press.

Meredith, M. (2006). The State of Africa: A fifty years of independence. London: Free press.

Mukhtar, M. H. (2003) Historical Dictionary of Somalia. USA: Maryland and oxford scarecrow press.

Phillips, James. (2002). Somalia and Al- Qaeida: Implications for the war on $\begin{array}{lllll}\text { terrorism. } & \text { Retrieved } & \text { April } & 11, & 2009\end{array}$ www.heritage.org/research/homelandsecurity

The rise of the Shabab, Somalia's Islamists. Somalia's powerful Islamist fighters. The Economist US .(Dec 20, 2008): 72EU. Retrieved April 11， 2009 from Expanded Academic ASAP. Gale. 